\title{
Myxobolus sp. can cause in vivo myoliquefaction in the host Paralichthys orbignyanus (Osteichthyes, Paralichthydae)
}

\author{
J. C. Eiras ${ }^{1, *}$, Joaber P. Júnior ${ }^{2}$, L. A. Sampaio ${ }^{3}$, R. Robaldo ${ }^{3}$, P. C. Abreu ${ }^{4}$ \\ ${ }^{1}$ Departamento de Zoologia e Antropologia, Faculdade de Ciências, and CIIMAR, Universidade do Porto, 4099-002 Porto, \\ Portugal \\ ${ }^{2}$ Fundação Universidade Federal do Rio Grande, Departamento de Ciências Morfobiológicas, Laboratório de \\ Ictioparasitologia, Av. Itália, 96201-900 Rio Grande, RS, Brasil \\ ${ }^{3}$ Fundação Universidade Federal do Rio Grande, Departamento de Oceanografia, Laboratório de Maricultura, Av. Itália, \\ 96201-900 Rio Grande, RS, Brasil \\ ${ }^{4}$ Fundação Universidade Federal do Rio Grande, Departamento de Oceanografia, Av. Itália, 96201-900 Rio Grande, \\ RS, Brasil
}

\begin{abstract}
We found intense myoliquefaction in vivo among specimens of wild and farmed South American flatfish Paralichthys orbignyanus Valenciennes, 1839. The soft flesh condition was attributed to Myxobolus sp. since the fish were not infected by myxosporeans which are usually associated with this condition (Kudoa spp.), and other causes (bacteria, fungi) were not found. The histopathology of the infection is described.
\end{abstract}

KEY WORDS: Myxobolus sp. P Paralichthys orbignyanus $\cdot$ Myxozoa $\cdot$ Myoliquefaction

Several Myxosporea species can cause post-mortem myoliquefactive necrosis in a number of fish species. The condition may be associated with Unicapsula seriolae, U. muscularis and Hexacapsula neothunni, and it occurs mainly when the flesh is warmed during cooking (Lester 1982). However, post-mortem myoliquefaction is most frequently caused by Kudoa spp. Moran et al. (1999) listed 44 species of Kudoa, and more species have been described subsequently. The following species have been reported as causes of enzymatic muscle degradation after host death: K. clupeidae, K. cruciformum, $K$. funduli, $K$. hystolitica, $K$. mirabilis, $K$. musculoliquefaciens, $K$. paniformis, $K$. peruvianus, $K$. rosenbuschi and $K$. thyrsites (Moran et al. 1999). K. lateolabracis causes the same effect (Yokoyama et al. 2004), and Kudoa sp. causes post-morten myoliquefaction of the North Pacific giant octopus Paroctopus dofleini (Yokoyama \& Masuda 2001).
Post-mortem myoliquefaction can be a limiting factor in the exploitation of wild species (Kabata \& Whitaker 1981, 1985) and for marine fish culture (Langdon 1991, Alvarez-Pellitero \& Sitjà-Bobadilla 1993, Barja \& Toranzo 1993, St-Hillaire et al. 1997, Moran et al. 1999, Kent et al. 2001, Dawson-Coates et al. 2003, Yokoyama et al. 2004). It causes economic loss in the fish canning industry (Gilman \& Eiras 1998).

Here, we report myoliquefaction, apparently caused by Myxobolus sp., in live specimens of farmed and wild flatfish Paralichthys orbignyanus Valenciennes, 1839. This flatfish is found in the southwestern Atlantic from Rio de Janeiro, Brazil, to at least Mar de la Plata, Argentina. It has important economic value.

Extensive and generalized myoliquefaction was first observed in 2 specimens at the Marine Aquaculture Station of the University of Rio Grande, Brazil. The fish were $1.5 \mathrm{yr}$ old and had been reared from eggs at the 
Station; they were kept in $1 \mathrm{~m}$ diameter round tanks, and fed with trash fish including Paralonchurus brasiliensis, Odonthesthes argentinensis, Micropogonias furnieri, Trachinotus marginatus, Brevortia pectinata and Mugil sp. juveniles. The 2 afflicted fish had breeding difficulties and their movements were restricted. They had zones of soft flesh and some degree of myoliquefaction (determined by touch) while other fish of the species were apparently normal. The degree of myoliquefation increased over time, with fish becoming soft over their entire bodies. Both specimens died. No further observations were made on these individuals. In another tank, 2 dead, completely liquefied specimens were discovered, and only the hard body structures remained intact.

A second observation was made recently in wild moribund specimens net collected at Rio Grande. The 2 live specimens (20 to $30 \mathrm{~cm}$ long) had body injuries, with a soft, milky cream of liquefied muscle flowing from the injuries. When the fish were handled, most muscle was transformed into milky cream and specimens died shortly after removal from the net. Tissue samples were taken immediately, fixed in formalin, routinely processed for histology, and stained with haemalumen and eosin, toluidene blue, Mallory's trichrome and Periodic Acid Schiff reagent. The remaining pieces of fish were fixed in formalin and thoroughly examined for Myxosporea.

Careful observation of the specimens revealed infection by Myxobolus sp. The parasites formed plasmodia containing only mature spores and were located inside muscle fibres near the fins. The fibres were either partially filled with the plasmodia (Fig. 1), or all of the fibre content was replaced by parasite spores. The

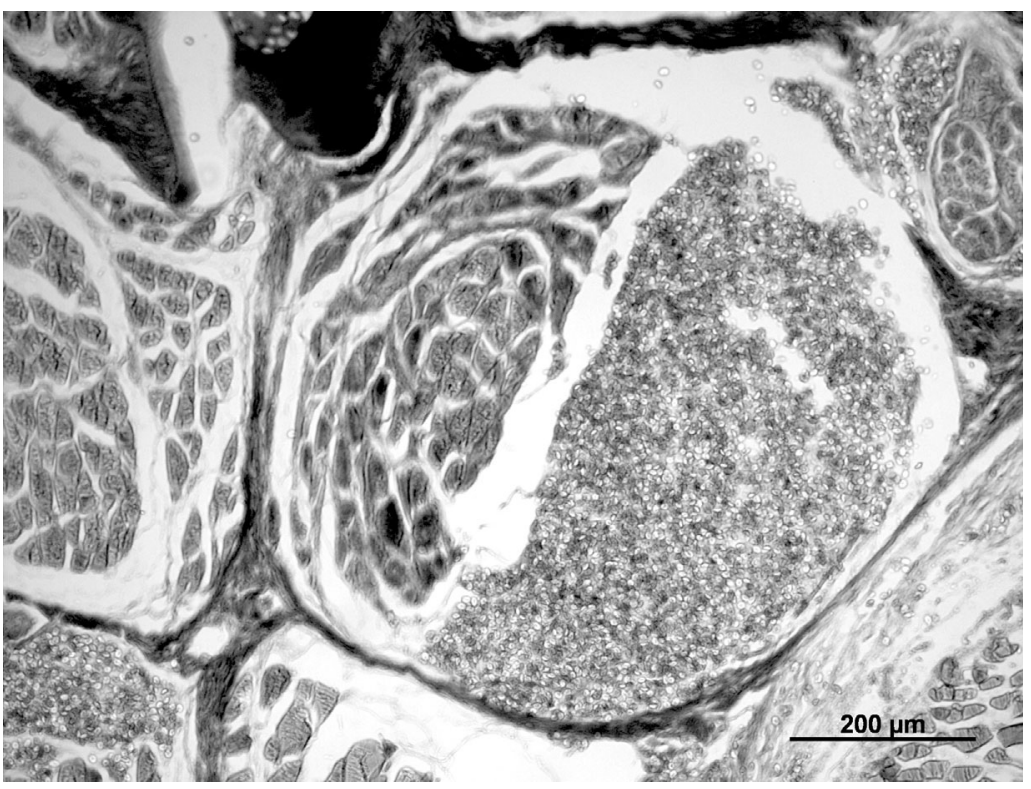

Fig. 1. Paralichthys orbignyanus infected by Myxobolus sp. Muscle fibres partially filled with Myxobolus sp. plasmodia. Mallory's triple stain

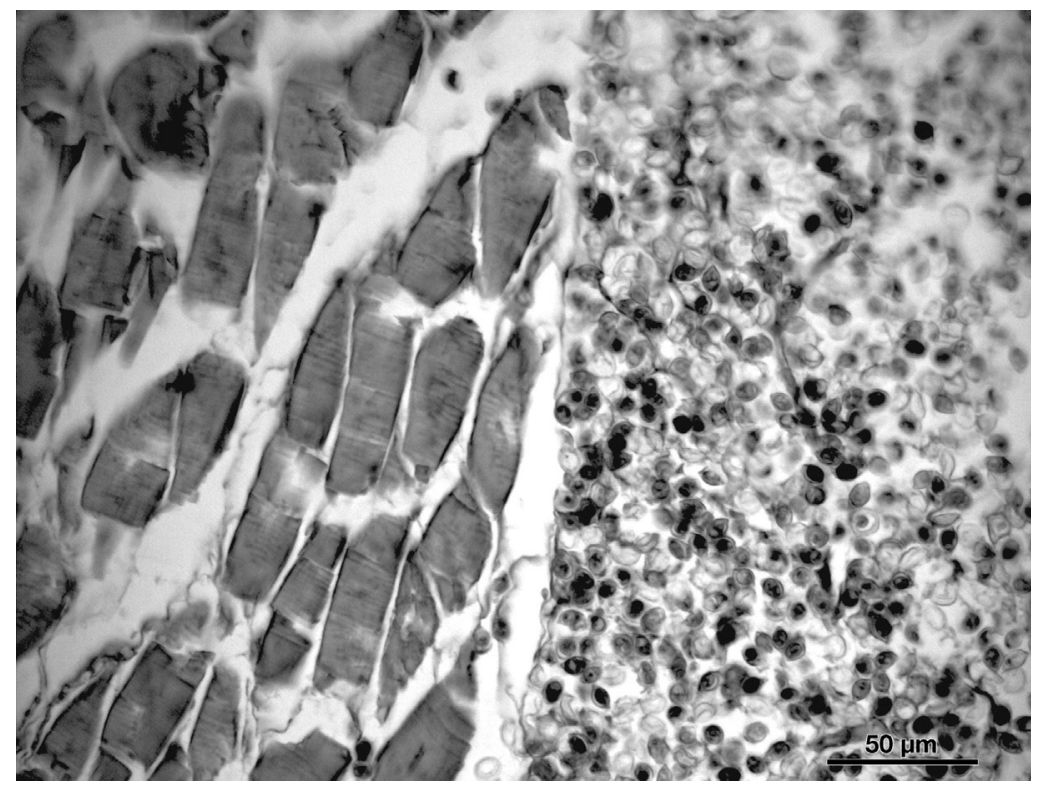

Fig. 2. Paralichthys orbignyanus infected by Myxobolus sp. Degeneration of the myofibrils inside infected muscle fibres. Mallory's triple stain

spores were more or less elliptical, with equal smooth cell valves about $1-1.5 \mu \mathrm{m}$ thick. Spores were 10.6 (10-11) $\mu \mathrm{m}$ long, $7 \mu \mathrm{m}$ wide and $6.5(6-7) \mu \mathrm{m}$ thick. Some spores were rounded and were $\sim 9 \mu \mathrm{m}$ in diameter. The polar capsules were equal in size, with a rounded anterior and pointed posterior extremity; they were 4.7 (4-5) $\mu \mathrm{m}$ long and $3 \mu \mathrm{m}$ wide. The number of coils of the polar filament could not be distinguished in formalin-fixed spores.
The myofibrils inside the infected fibres showed some degree of degeneration, with partial loss of myofibrillar detail and striation (Fig. 2). The main changes in the muscle were observed in regions some distance from the plasmodia, where no spores were present; both dorsal and ventral muscles appeared affected. In these areas the muscle cells lost their integrity, the myofibrilar detail and striation was 


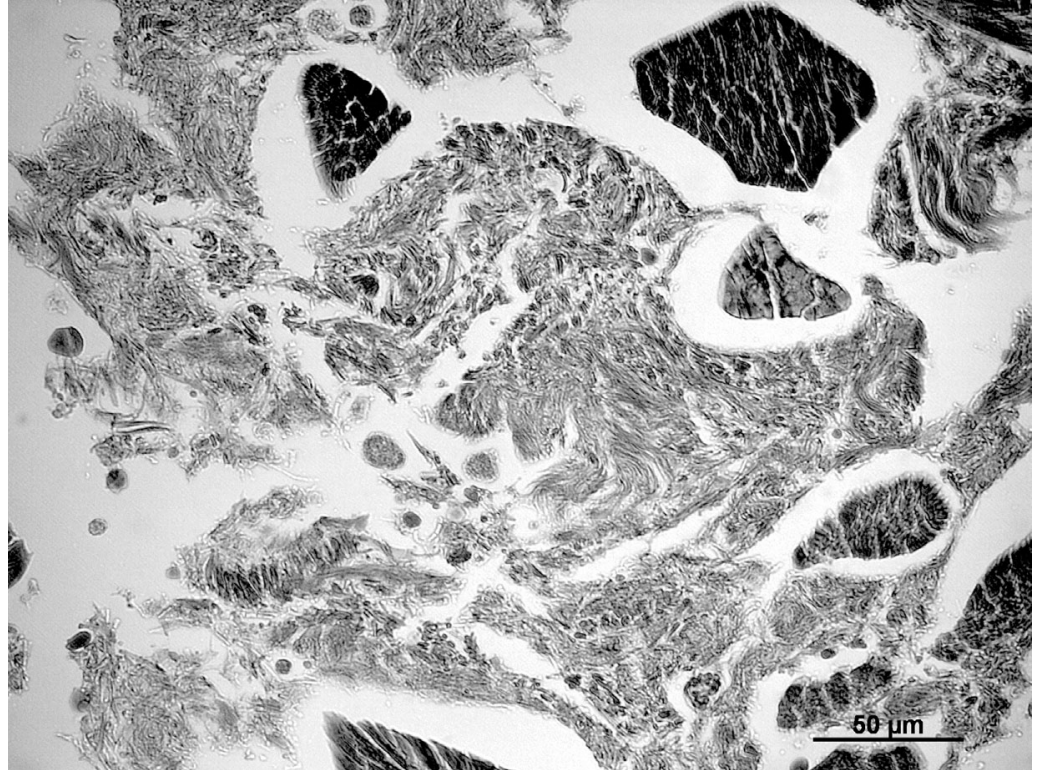

Fig. 3. Paralichthys orbignyanus infected by Myxobolus sp. Extensive degeneration and myoliquefaction of muscle. Toluidene blue stain

continually, but removed by vascular perfusion in the live fish, or these enzymes may be released only upon death of spores or plasmodia. Observations of Langdon (1991) on the infection of Coryphaena hippurus by $K$. thyrsites suggested that to facilitate the release of the spores the parasite initiated excretion of the liquefactive enzymes in response to fish death. However, Patashnik et al. (1982) reported accumulation of the enzymes within the pseudocyst, concluding that diffusion from pseudocysts after host death causes myoliquefaction. Proteolytic enzymes are apparently not associated with the spores, but are produced by non-sporous elements of the plasmodium (Stehr \& Whitaker 1986). Moran et al. (1999) reviewed literature on milky flesh caused by Kudoa spp.

Why muscle liquefaction in our samples began before host death is unknown. If liquefactive enzymes were produced continually, then their normal

removed, and hyaline degeneration and myoliquefaction were evident (Fig. 3). Neither inflammation nor a macrophage response was detected.

Careful examination of the specimens showed that other myxosporeans (Kudoa spp.) were absent from the fish, and bacteria and fungi were not detected. Therefore, it is very likely that the muscle changes and myoliquefaction were caused by Myxobolus sp.

As far as we are aware, this is the first description of myoliquefaction caused by Myxobolus sp. Postmortem myoliquefaction caused by Kudoa has been reported for congeners of the fish we examined, including wild Paralichthys adspersus infected by K. thyrsites in Chile (Castro \& Burgos 1996), which has also parasitized farmed $P$. olivaceus in Japan (Yokoyama et al. 2004).

Occurrence of myoliquefaction in live hosts is unusual. Lom \& Dyková (1992) reported only one record of myoliquefaction in a living fish, i.e. Atherestes evermani from the Bering Sea that was infected by a Kudoa sp. Later, Davies et al. (1998) observed muscle necrosis and milky condition caused by Kudoa sp. (superficially resembling $K$. novae) in live gobies (Pomastochistus microps and Gobius paganellus) from Devon, UK. In this case, rod-shaped bacteria, which may have been secondary invaders, might also have contributed to tissue necrosis. All other observations of myoliquefaction caused by myxosporeans are of postmortem changes in the muscle of the host. Lester (1982) maintained that enzymes produced by the parasites and responsible for the soft flesh may be excreted removal or inhibition must have been impaired in some way. Assuming that proteolytic enzymes were localized within the plasmodia and released to other sites as the host cells broke down after the death of the host (Patashnik et al. 1982), outward diffusion of the enzymes from the plasmodia must have occurred in the live fish. What triggered this myoliquefaction in vivo is unknown, although stress of capture caused by netting the wild specimens may have played a role.

The current material was compared with 744 nominal species of Myxobolus listed by Eiras et al. (2005), including 30 species parasitic in the muscle of fish, and 28 occurring simultaneously in muscle and other organs. However, in spite of sharing features with some of these species, the absence of fresh spores in the Myxobolus we examined precludes species identification.

\section{LITERATURE CITED}

Alvarez-Pellitero P, Sitjà-Bobadilla A (1993) Pathology of Myxosporea in marine fish culture. Dis Aquat Org 17: 229-238

Barja JL, Toranzo A (1993) Myoliquefaction post-morten caused by the myxosporean Kudoa thyrsites in reared Atlantic salmon in Spain. Bull Eur Assoc Fish Pathol 13:86-88

Castro CR, Burgos R (1996) Kudoa thyrsithes (Myxozoa, Multivalvulida) causing 'milky condition' in the musculature of Paralichthys adspersus (Neopterigii, Pleuronectiformes, Paralichthyidae) from Chile. Mem Inst Oswaldo Cruz 91:163-164

Davies AJ, Andrews T, Upton NDP, Matthews RA (1998) Kudoa as a contributory cause of muscle necrosis in gobies. Bull Eur Assoc Fish Pathol 18:62-66 
Dawson-Coates JA, Chase JC, Funk V, Booy MH and 5 others (2003) The relationship between flesh quality and numbers of Kudoa thyrsites plasmodia and spores in farmed Atlantic salmon, Salmo salar L. J Fish Dis 26:451-459

Eiras JC, Molnár K, Lu YS (2005) Synopsis of the species of Myxobolus Bütschli, 1882 (Myxozoa: Myxosporea: Myxobolidae). Syst Parasitol 61:1-46

Gilman MM, Eiras JC (1998) Kudoa sp. (Myxosporea, Multivalvulida) infecting Sardina pilchardus (Walb., 1792) off the Portuguese coast. Res Rev Parasitol 58:135-137

Kabata Z, Whitaker DJ (1981) Two new species of Kudoa (Myxosporea: Multivalvulida) parasitic in the flesh of Merluccius productus (Ayres, 1855) (Pisces: Teleostei) in the Canadian Pacific. Can J Zool 69:2085-2091

Kabata Z, Whitaker DJ (1985) Parasites as a limiting factor in exploitation of Pacific Whiting, Merluccius productus. Mar Fish Rev 47:55-59

Kent ML, Andree KB, Bartholomew JL, El-Matbouli M and 12 others (2001) Recent advances in our knowledge of the Myxozoa. J Eukaryot Microbiol 48:395-413

Langdon JS (1991) Myoliquefaction post-morten ('milky flesh') due to Kudoa thyrsites (Gilchrist) (Myxosporea: Multivalvulida) in mahi mahi, Coryphaena hippurus L. J Fish Dis 14:45-54

Lester RJG (1982) Unicapsula seriolae n. sp. (Myxosporea, Multivalvulida) from Australian yellowtail kingfish Seriola lalandi. J Protozool 29:584-587

Lom J, Dyková I (1992) Protozoan parasites of fishes. Develop-

Editorial responsibility: Dieter Steinhagen,

Hannover, Germany ments in aquaculture and fisheries science, Vol 26. Elsevier, Amsterdam

Moran JDW, Whitaker DJ, Kent ML (1999) A review of the myxosporean genus Kudoa Meglitsch, 1947, and its impact on the international aquaculture industry and commercial fisheries. Aquaculture 172:163-196

Patashnik M, Groninger HS, Barnett H, Kudo G, Koury B (1982) Pacific whiting Merluccius productus: I. Abnormal texture caused by myxosporidium induced proteolysis. Mar Fish Rev 44:1-12

Stehr C, Whitaker DJ (1986) Host-parasite interaction on myxosporeans Kudoa paniformis Kabata \& Whitaker, 1981 and Kudoa thyrsites (Gilchrist, 1924) in the muscle of Pacific whiting, Merluccius productus (Ayres): an ultrastructural study. J Fish Dis 9:505-517

St-Hilaire S, Hill M, Kent ML, Whitaker DJ, Ribble C (1997) A comparative study of muscle texture and intensity of Kudoa thyrsites infection in farmed-reared Atlantic salmon Salmo salar on the pacific coast of Canada. Dis Aquat Org 31:221-225

Yokoyama H, Masuda K (2001) Kudoa sp. (Myxozoa) causing a post-morten myoliquefaction of North-Pacific giant octopus Paroctopus dofleini (Cephalopoda: Octopodidae). Bull Eur Assoc Fish Pathol 21:266-268

Yokoyama H, Whipps CM, Kent ML, Mizuno K, Kawakami H (2004) Kudoa thyrsites from Japanese flounder and Kudoa lateolabracis n. sp. from Chinese sea bass: causative myxozooans of post-morten myoliquefaction. Fish Pathol 39:79-85

Submitted: June 15, 2007; Accepted: July 30, 2007

Proofs received from author(s): September 17, 2007 